\title{
pH-Induced physicochemical modifications of native phosphocaseinate suspensions: Influence of aqueous phase
}

\author{
MH Famelart, F Lepesant, F Gaucheron, \\ Y Le Graet, P Schuck
}

Laboratoire de recherches de technologie laitière, INRA,

65, rue de Saint-Brieuc, 35042 Rennes cedex, France

(Received 2 November 1995; accepted 29 May 1996)

\begin{abstract}
Summary - pH-Induced physicochemical changes and rennet coagulation times of casein micelle suspensions have been studied with native phosphocaseinate powder dissolved in water, $0.1 \mathrm{~mol} L-1$ $\mathrm{NaCl}$ and milk ultrafiltrate. An increase in ionic strength between water and $\mathrm{NaCl}$ led to higher diffusible calcium and phosphorus, to greater micelle voluminosity and to greater casein and mineral solubilization during acidification. Dissolution of the phosphocaseinate in ultrafiltrate resulted in physicochemical properties very close to milk. The acidification process can be divided into five successive steps. Relations between physicochemical changes are discussed, together with the reduction of rennet coagulation time with $\mathrm{pH}$ and ionic strength reduction.
\end{abstract}

micelle / pH / ionic strength / calcium / phosphorus / native phosphocaseinate / rennet coagulation / acid coagulation

Résumé - Modifications physicochimiques des suspensions de phosphocaséinate natif induites par le pH : influence de la phase aqueuse. L'effet $d u \mathrm{pH}$ sur les évolutions physicochimiques de suspensions de micelles de caséine, ainsi que sur les temps de coagulation présure, a été étudié sur une poudre de phosphocaséinate natif reconstituée dans de l'eau, une solution $0,1 \mathrm{~mol}^{\mathrm{L}^{-1}}$ en $\mathrm{NaCl}$ et un ultrafiltrat de lait. L'augmentation de force ionique entre l'eau et $\mathrm{NaCl}$ provoque une augmentation des teneurs en calcium et en phosphore diffusibles, une plus grande voluminosité des micelles, et une augmentation de la solubilisation des caséines et des minéraux intervenant lors de l'acidification. La solubilisation du phosphocaséinate natif dans l'ultrafiltrat conduit à un comportement proche du lait. L'acidification peut être divisée en cinq phases successives. Les relations entre les évolutions physicochimiques sont discutées, ainsique la diminution des temps de coagulation présure avec la baisse du $\mathrm{pH}$ et de la force ionique.

micelle / pH / force ionique / calcium / phosphore / phosphocaséinate natif / coagulation présure / coagulation acide 


\section{INTRODUCTION}

Acidification of milk is fundamental to many industrial dairy processes such as casein, cheese and yoghurt manufacture. Previous work established that during the decrease of $\mathrm{pH}$, calcium and inorganic phosphate were solubilized from the micelles (Brulé et al, 1974; Van Hooydonk et al, 1986a; Visser et al, 1986; Dalgleish and Law, 1989; le Graet and Brulé, 1993), caseins dissociate from the micelles near $\mathrm{pH} 5.4$ at $20^{\circ} \mathrm{C}$, and then reassociate (Roefs et al, 1985; Van Hooydonk et al, 1986a; Dalgleish and Law, 1988), micelle size decreases (Heertje et al, 1985; Roefs et al, 1985; Banon and Hardy, 1991, 1992), zeta potential decreases (Darling and Dickson, 1979; Banon and Hardy, 1992) or reaches a minimum at pH 5.4 and a maximum at $\mathrm{pH} 5.1$ (Schmidt and Poll, 1986) and solvation decreases (Tarodo de la Fuente and Alais, 1975; Snoeren et al, 1984; Creamer, 1985; Visser et al, 1986). Finally, at its isoelectric $\mathrm{pH}$, casein becomes aggregated in a network.

However, the understanding of the role and the sequence of each of these changes is still limited. Heertje et al (1985) suggested that the particles aggregating at $\mathrm{pH}$ 5.0 are different from the native ones, ie, those at physiological $\mathrm{pH}$. The complex change of zeta potential with $\mathrm{pH}$ reduction (Schmidt and Poll, 1986) can be explained by the $\beta$-casein acting as the starting point for the casein aggregation (Heertje et al, 1985; Visser et al, 1986) or by the $\mathrm{pH}$ dependent affinity of calcium for micellar casein or inorganic phosphate (Schmidt and Poll, 1986).

In the present paper, we describe the behaviour of casein micelles during acidification. Tangential membrane microfiltration of milk by the Bactocatch procedure as proposed by Fauquant et al (1988), followed by spray drying of the diafiltrated retentate (Schuck et al, 1994) results in an enriched micellar caseinate called native phospho- caseinate powder. This product is close in protein composition to a commercial calcium caseinate powder (Schuck et al, 1994) and it exhibits reduced rennet clotting time and increased gel development kinetics (Pierre et al, 1992). Hence, this powder may be regarded as a suitable way to standardise milk in cheese making processes as described by Salles et al (1995), because it enhances technological properties by increasing the protein concentration, without increasing the lactose content. Moreover, it may be regarded as an attractive way to produce various micellar suspensions.

The aim is to establish the effect of the aqueous phase and of the ionic strength on casein and mineral dissociation during acidification and to show relationships between the various physicochemical changes. The native phosphocaseinate powder was dissolved in water, $0.1 \mathrm{~mol} \mathrm{~L}^{-1}$ $\mathrm{NaCl}$ solution, and milk ultrafiltrate. Acidification was induced by adding gluconodelta-lactone $(G D L)$, because that is a simple system to reach desired and stable $\mathrm{pH}$ values in quiescent conditions, without using bacteria.

\section{MATERIALS AND METHODS}

\section{Preparation of native phosphocaseinate suspensions (NPCS)}

The native phosphocaseinate powder $\mathrm{P} 1$ was prepared according to Pierre et al (1992) and Schuck et al (1994). Chemical composition of this powder is reported in table I. The powder was reconstituted at $50^{\circ} \mathrm{C}$ to a concentration of $25 \mathrm{~g} \mathrm{~L}^{-1}$ of casein (ie, $31.94 \mathrm{~g} \mathrm{~L}^{-1}$ of powder); $0.2 \mathrm{~g} \mathrm{~L}^{-1}$ sodium azide was added to the aqueous phase used for the reconstitution, ie, deionized water or $0.1 \mathrm{~mol} \mathrm{~L}^{-1} \mathrm{NaCl}$ solution prepared in deionized water or milk ultrafiltrate (UF). Raw whole milk (Besnier Bridel, l'Hermitage, France) used to prepare UF was skimmed twice at $43^{\circ} \mathrm{C}$ with Westfalia Separator DD100Z. UF was obtained by ultrafiltration on a spiral membrane of $3000 \mathrm{Da}$ molecular mass cut-off 
Table I. Chemical composition of the native phosphocaseinate powder.

Composition chimique de la poudre de phosphocaséinate natif.

\begin{tabular}{lc}
\hline & $g g^{-1}$ \\
\hline Dry matter & 926.20 \\
& \\
Total nitrogen ${ }^{*}$ & 836.16 \\
NCN. & 53.40 \\
NPN & 4.33 \\
Lactose & 6.7 \\
Ashes & 81.50 \\
Ca & \\
Na & 28.49 \\
K & 0.48 \\
Mg & 0.89 \\
Cl & 1.00 \\
Citrate & 1.57 \\
& 1.32
\end{tabular}

*Using 6.38 as converting factor; NCN, non-casein nitrogen; NPN, non-protein nitrogen.

Après calcul avec le facteur 6,38; NCN : azote non caséinique; NPN : azote non protéique.

(MMCO) (S10Y3, Amicon, Epernay, France) at $50{ }^{\circ} \mathrm{C}$. Preparation of native phosphocaseinate suspensions (NPCS) in each aqueous phase and subsequent analyses were carried out in duplicate.

\section{Acidification of NPCS}

Defined amounts of GDL (Lysactone, Roquette Frères, Lestrem, France) were added at $20^{\circ} \mathrm{C}$ to NPCS to reach pH values between 4.0 and 7.5 , after $15 \mathrm{~h}$ at $20^{\circ} \mathrm{C}$. After GDL addition, NPCS were stirred and left at $20^{\circ} \mathrm{C}$ in a water bath. The $\mathrm{pH}$ obtained in these conditions was related in advance by a polynomial function (maximal degree five) to the amount of GDL. This equation allows to compute the content of $\mathrm{GDL}$ to reach precise values of $\mathrm{pH}$. One $\mathrm{mol} \mathrm{L}^{-1}$ $\mathrm{NaOH}$ was added to micelle suspensions in UF to reach $\mathrm{pH} 7.0$.

\section{Fractionation}

Each sample was ultracentrifuged at $20^{\circ} \mathrm{C}$ during $2 \mathrm{~h}$ at $75000 \mathrm{~g}$ in a L8-55 ultracentrifuge (Beckman Instrument France, Gagny, France), with a 50.2.Ti rotor. Supernatants were carefully removed by syringe, and micellar pellets were drained for $5 \mathrm{~min}$.

$1 \mathrm{~h}$ centrifugation at $1000 \mathrm{~g}$ at $20^{\circ} \mathrm{C}$ was carried out in a Cryofuge M 7000 (Heraeus Sepatech, Les Ulis, France).

Ultrafiltration was carried out at $20^{\circ} \mathrm{C}$ on a Centriflo CF 25 (MMCO $25000 \mathrm{Da}$, Amicon, Epernay, France) at $500 \mathrm{~g}$ during $1 \mathrm{~h}$. The first $2 \mathrm{~mL}$ of ultrafiltrate and the concentrated suspensions were discarded and $7 \mathrm{~mL}$ of each sample were then ultrafiltered.

\section{Physicochemical analysis}

Calcium and phosphorus $(P)$ contents were determined by atomic absorption spectrometry (Brulé et al, 1974) and International Dairy Federation standard method (1987), respectively, on micelle suspensions and Centriflo ultrafiltrates. Concentrations of minerals in ultrafiltrate were converted into diffusible mineral concentrations in NPCS by multiplying by a correction factor of 0.96 , according to Pierre and Brulé (1981). This correction accounted for excluded volume effect, but neglected the Donnan effect (Holt, 1985). This probably caused a systematic error for diffusible amounts. Micellar mineral contents were calculated by subtracting the diffusible concentrations from the total one.

Total nitrogen contents (TN) of 1000- $g$ supernatants were estimated by Kjeldahl with 6.38 as conversion factor.

Non-micellar caseins were defined as caseins which do not sediment after $2 \mathrm{~h}$ centrifugation at $75000 \mathrm{~g}$. They were obtained by optical density measurements $(\mathrm{OD}$ ) at $280 \mathrm{~nm}$ (Uvikon 810 , Kontron SA, St-Quentin-en-Yvelines, France) of the supernatants diluted in $10 \mathrm{mmol} \mathrm{L}^{-1}$ EDTA (pH 10) (adapted from Driehuis and Teernstra, 1992). ODs of suspensions and supernatants were calculated by multiplying the OD measured by the dilution factor. For NPCS dissolved in water and $\mathrm{NaCl}$, the percent of $\mathrm{OD}$ in supernatant $(\mathrm{OD} \%)$ at each $\mathrm{pH}_{\mathrm{i}}$ was calculated as:

$$
\text { OD } \%=\frac{\text { OD of supernatant at } \mathrm{pH}_{\mathrm{i}}}{\text { OD of NPCS at } \mathrm{pH}_{\mathrm{i}}} \times 100
$$

while for the NPCS dissolved in UF the calculation was:

$$
\mathrm{OD} \%=\frac{\mathrm{OD} \text { of supernatant at } \mathrm{pH}-\mathrm{OD} \text { of UF used }}{\mathrm{OD} \text { of NPCS at } \mathrm{pH}-\mathrm{OD} \text { of UF used }} \times 100
$$

to compare the solubilization of caseins with the $\mathrm{pH}$ in the various media. OD values of the two 
UF were 5.00 and 6.04 . Supernatants which gave the higher OD\% were analysed by HPLC on reversed-phase C4 column according to Jaubert and Martin (1992). $\beta$-casein (Eurial, Nantes, France) was used as standard for calibration, and absorptivity values of the major caseins were used for quantification (Swaisgood, 1992).

Drained pellets of $75000 \mathrm{~g}$ centrifugation were dried at $103{ }^{\circ} \mathrm{C}$ during $7 \mathrm{~h}$ and the solvation in $\mathrm{g}$ of water per $\mathrm{g}$ of dry pellet were deduced. The total sediment volume, $\mathrm{V}_{\mathrm{s}}\left(\mathrm{mL} \mathrm{g}^{-1}\right)$ was calculated as:

$$
\mathrm{V}_{5}=\mathrm{C}_{\text {cas }} \times \mathrm{v}_{\text {cas }}+\mathrm{C}_{\mathrm{W}} \times \mathrm{V}_{\mathrm{W}}
$$

where $C_{c a s}, C_{w}$ are the casein and water concentrations in the wet pellet $\left(\mathrm{g} \mathrm{g}^{-1}\right)$, respectively, and $v_{c a s}, v_{w}$ are the specific volumes of caseins $\left(0.7 \mathrm{~mL} \mathrm{~g}^{-1}\right)$ and water $\left(1.0 \mathrm{~mL} \mathrm{~g}^{-1}\right)$ (Van Hooydonk et al, 1986a). We assumed whey proteins, lactose and mineral contributions to be negligible, because their concentrations in the pellet were almost constant or low. Casein voluminosity obtained by pellet solvation measurements, $V_{\text {pellet, }}$, is $V_{s} / C_{\text {cas }}\left(\mathrm{mL} \mathrm{g}^{-1}\right)$ (Van Hooydonk et al, 1986a).

Apparent dynamic viscosity of micelle suspensions was measured at $20^{\circ} \mathrm{C}$ using a coaxial cylinder viscometer LS30 (Contraves, Zurich, Switzerland) at $94.5 \mathrm{~s}^{-1}$ strain rate. Relative viscosity was calculated as the ratio of dynamic viscosity of NPCS and of the measured values for dynamic viscosity of water $(1.00 \mathrm{mPa} \mathrm{s}), \mathrm{NaCl}$ $(0.95 \mathrm{mPa}$ s) or UF $(1.09 \mathrm{mPa}$ s). Voluminosity was calculated according to the equation of Eilers, cited in Van Hooydonk et al, 1986a):

$$
\text { irel }=\left(1+\frac{1.25 \Phi}{1-\frac{\Phi}{\Phi \max }}\right) 2
$$

where $\eta_{\text {rel }}$ is the relative viscosity of the NPCS, $\Phi$ is the volume fraction of casein and $\Phi_{\max }$, is a constant of value 0.79 . $\phi$ is equal to $C_{\text {cas }} \times V_{\text {visc }}$, where $\mathrm{C}_{c a s}$ is the casein concentration of caseinate $\left(25.10^{-3} \mathrm{~g} \mathrm{~mL}^{-1}\right)$ and $V_{\text {visc, }}$, the voluminosity obtained by viscosity measurements. Whey proteins were neglected because their concentrations were very low.

Average micelle diameters were estimated by a dynamic light-scattering method on a Coulter N4MD apparatus (Coultronics, Margency, France) at $20^{\circ} \mathrm{C}$ after $1: 300$ dilution in Dalgleish buffer (1984) (Pierre et al, 1995). The computed autocorrelation function of the scattered light is related to the intensity-weighted average diffu- sion coefficient and to the particle diameter, assuming a log-Gaussian distribution. Diluted suspensions were stabilised for $10 \mathrm{~min}$ inside the cell holder, and a measurement of light intensity scattered at $90^{\circ}$ during $300 \mathrm{~s}$ was carried out. Each suspension was acidified in duplicate and means were calculated so that each curve represents four experiments.

\section{Rheological and scanning electron microscopy of acid gels}

A constant speed cone penetrometer (Stevens LFRA) was used to evaluate firmness of acid gels with a cone of $90^{\circ}$ moving $10 \mathrm{~mm}$ inside the gel at $2 \mathrm{~mm} \mathrm{~s}^{-1}$, as described by Korolczuk and Mahaut (1988). GDL was added to NPCS to reach $\mathrm{pH} 4.4$, as described above. Just after addition, NPCS was placed in the test cup of $25 \mathrm{~mm}$ height and $62 \mathrm{~mm}$ diameter. The gel height was $20 \mathrm{~mm}$. Measurements of firmness in Pa were performed at room temperature.

Gel samples at $\mathrm{pH} 4.4(3 \times 3 \times 2 \mathrm{~mm})$ were fixed at room temperature for $48 \mathrm{~h}$ in a solution of $2.5 \%$ glutaraldehyde prepared in $0.1 \mathrm{~mol} \mathrm{~L}^{-1}$ ( $\mathrm{pH} 7.2$ ), sodium cacodylate, dehydrated in alcohol series and critical point dried from carbon dioxide. They were fractured by hand, mounted on stubs and sputter coated with gold (about 70 $\mathrm{nm}$ ). A Philips scanning electron microscope (XL 20) was operated at $12 \mathrm{kV}$. Particle sizes were determined on screen.

\section{Renneting}

Hansen rennet powder (Boll, Arpajon, France) was prepared at $50 \mathrm{~g} \mathrm{~kg}^{-1}$ as described by Famelart (1994) and used immediately after thawing at $1 \mathrm{~mL}$ per L of NPCS. Coagulation time of non-acid-aggregated samples prewarmed during 30 min was evaluated with a Formagraph at $30^{\circ} \mathrm{C}$.

\section{RESULTS}

\section{Initial NPCS characterization}

The pHs of NPCS were $7.45,7.36$ and 6.73 in water, $\mathrm{NaCl}$ and UF, respectively.

Diffusible calcium and phosphorus contents were higher for NPCS in $\mathrm{NaCl}$ than in water (figs 2, 3). At pH 6.7, for NPCS dissolved in water, diffusible calcium and 
phosphorus were 2.862 and $1.677 \mathrm{mmol}$ $\mathrm{kg}^{-1}$, respectively. In $\mathrm{NaCl}$, these values became 5.525 and $2.435 \mathrm{mmol} \mathrm{kg}^{-1}$ (table II). Mineral diffusible contents of NPCS in UF were 8.337 and $13.339 \mathrm{mmol} \mathrm{kg}^{-1}$ for calcium and phosphorus, respectively. They are increased by the mineral contents of the ultrafiltrate used for dissolution. However, it appears that diffusible minerals of NPCS in UF were less than the diffusible content of NPCS in water plus the UF content (table II).

A higher content of non-micellar casein (fig 5) was observed for NPCS dissolved in water $(18 \%$ of $\mathrm{OD})$, than in $\mathrm{NaCl}(11.5 \%)$ and in UF $(9 \%)$, and micelle sizes (fig 7) were 210,220 and $240 \mathrm{~nm}$, respectively. Initial solvation of NPCS (fig 8) dissolved in $\mathrm{NaCl}$ was $25 \%$ higher than the others.

\section{Acidification}

Figure 1 shows $\mathrm{pH}$ values of NPCS obtained with increasing amounts of GDL. The acidification curves were similar. The initial $\mathrm{pH}$ values were lower for NPCS in UF than in water or $\mathrm{NaCl}$. GDL amounts needed to reach $\mathrm{pH} 4$ were higher for NPCS in UF than in water or $\mathrm{NaCl}$.

\section{Mineral solubilization with $\mathrm{pH}$}

Between $\mathrm{pH} 7.0$ and 5.2, diffusible calcium and phosphorus contents increased continuously, while below pH 5.2, diffusible calcium still increased and diffusible phosphorus decreased (figs 2,3 ).

The extent of solubilization during successive steps of $\mathrm{pH}(\mathrm{pH} 6.7-6.0 ; \mathrm{pH} 6.0-$ 5.6; $\mathrm{pH}$ 5.6-5.2; $\mathrm{pH} 5.2-4.0$ ) as was done by Le Graet and Brulé (1993) showed a substantial increase of diffusible minerals during the step $\mathrm{pH} 6.7-6.0$ and $\mathrm{pH} 6.0-5.6$ for NPCS dissolved in high ionic strength. It is obvious from figures 2 and 3 that diffusible minerals of NPCS dissolved in $\mathrm{NaCl}$ reached the final, low values at higher $\mathrm{pH}$.

Linear relations were found between $\mathrm{mi}-$ cellar calcium and micellar inorganic phosphorus from $\mathrm{pH} 7.0$ to $\mathrm{pH} 5.3$ (fig 4). Slopes were higher for NPCS in water than in the other solvents.

Table II. Calcium (Ca) and phosphorus (P) contents $\left(\mathrm{mmol} \mathrm{kg}^{-1}\right)$ of UF (milk ultrafiltrate used to dissolve the powder) and diffusible mineral contents of the native phosphocaseinate suspensions (NPCS) dissolved in water, $0.1 \mathrm{~mol} \mathrm{~L}^{-1} \mathrm{NaCl}$ and $\mathrm{UF}$ at $\mathrm{pH} 6.7$ and $20^{\circ} \mathrm{C}$.

Calcium (Ca) et phosphore $(P)\left(m m o l ~ \mathrm{~g}^{-1}\right)$ de l'UF (ultrafiltrat de lait servant à dissoudre la poudre) et minéraux diffusibles des suspensions de phospho-caséinate natif (NPCS) solubilisé dans l'eau, $\mathrm{NaCl} 0,1 \mathrm{~mol} \mathrm{~L}^{-1}$ et l'UF à $\mathrm{pH} 6,7$ et $20^{\circ} \mathrm{C}$.

\begin{tabular}{|c|c|c|c|c|c|c|}
\hline & & \multirow{2}{*}{$\begin{array}{l}\text { Total content } \\
\text { of UF } \\
\left(\mathrm{mmol} \mathrm{kg}^{-1}\right)\end{array}$} & \multicolumn{4}{|c|}{ Diffusible content ( $\mathrm{mmol} \mathrm{kg}^{-1}$ ) of: } \\
\hline & & & $\begin{array}{c}\text { NPCS in } \\
\text { water }\end{array}$ & $\begin{array}{l}\text { NPCS in } 0.1 \\
\mathrm{~mol} \mathrm{~L}^{-1} \mathrm{NaCl}\end{array}$ & $\begin{array}{l}\text { NPCS in UF } \\
\text { calculated }\end{array}$ & $\begin{array}{c}\text { NPCS in } \\
\text { UF }\end{array}$ \\
\hline \multirow[t]{2}{*}{$\mathrm{Ca}$} & $\exp 1^{\star *}$ & 7.100 & 2.700 & 5.525 & 9.800 & 8.450 \\
\hline & $\exp 2^{* *}$ & 7.775 & 3.025 & 5.525 & 10.800 & 8.225 \\
\hline \multirow[t]{2}{*}{$\mathrm{P}$} & $\exp 1^{* *}$ & 13.677 & 1.613 & 2.387 & 15.290 & 13.903 \\
\hline & $\exp 2^{\star \star}$ & 12.677 & 1.742 & 2.484 & 14.419 & 12.774 \\
\hline
\end{tabular}

- On the assumption that diffusible content of NPCS dissolved in water added up to the UF content: $9.800 \mathrm{mmol}$ $\mathrm{kg}^{-1}=$ total content of UF $(7.100)+$ diffusible content of NPCS in water (2.700). ${ }^{\star *}$ Two replicates are presented. * En supposant qu'il y a addition des concentrations diffusibles du NPCS dissout dans l'eau et des concentrations de I'UF : $9,800 \mathrm{mmol} \mathrm{kg}^{-1}=$ teneur en minéraux totaux de I'UF $(7,100)+$ teneur en minéraux diffusibles des suspensions de phosphocaséinate natif (NPCS) dans l'eau (2,700). "* Deux répétitions sont présentées. 


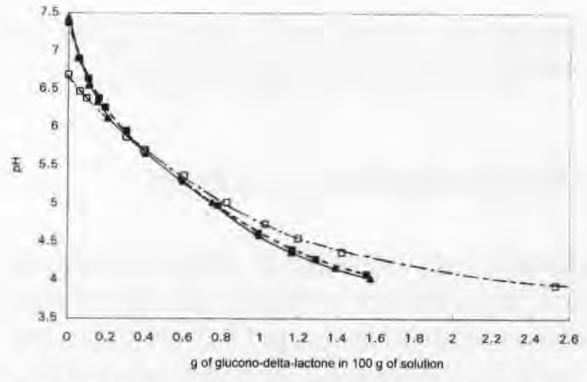

Fig 1. Values of $\mathrm{pH}$ after glucono-delta-lactone (GDL) addition in native phosphocaseinate suspensions in water (A), $0.1 \mathrm{~mol} \mathrm{~L}^{-1} \mathrm{NaCl}(\mathbf{E})$ and milk ultrafiltrate $(\square)$. Contents of GDL are expressed in $\mathrm{g}$ added for $100 \mathrm{~g}$ of final solution. GDL (lysactone) was added at $20^{\circ} \mathrm{C}$ and $\mathrm{pH}$ were measured after $15 \mathrm{~h}$ incubation at $20^{\circ} \mathrm{C}$. Évolution du $\mathrm{pH}$ après l'addition de gluconodelta-lactone (GDL) aux suspensions de phosphocaséinate natif dans l'eau ( $\mathbf{\Delta}), \mathrm{NaCl}$ $0,1 \mathrm{~mol} \mathrm{~L}^{-1}$ (四) et l'ultrafiltrat de lait ( $(\square)$. Les contenus en $G D L$ sont exprimés en $g$ ajoutés pour $100 \mathrm{~g}$ de suspension finale. La GDL (lysactone) était ajoutée à $20^{\circ} \mathrm{C}$ et le $\mathrm{pH}$ était mesuré après 15 heures d'incubation à $20^{\circ} \mathrm{C}$.

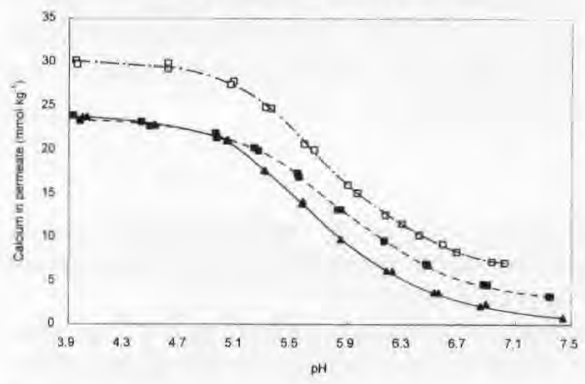

Fig 2. Solubilization with the $\mathrm{pH}$ at $20{ }^{\circ} \mathrm{C}$ of calcium from suspensions of native phosphocaseinate. Concentrations of calcium in permeates obtained by ultrafiltration on Centriflo CF25 are presented. The $\mathrm{pH}$ values were obtained after the addition of GDL during $15 \mathrm{~h}$ at $20^{\circ} \mathrm{C}$. Two replicates for each medium are presented. Same symbols as in the legend to figure 1 .

Solubilisation du calcium des suspensions de phosphocaséinate natif avec le pHà $20^{\circ} \mathrm{C}$. Les concentrations en calcium dans les perméats obtenus sur Centriflo CF25 sontprésentées. Les différentes valeurs du $\mathrm{pH}$ étaient obtenues 15 heures après l'addition de la GDL à $20^{\circ} \mathrm{C}$. Deux répétitions de chaque suspension sont présentées. Mêmes symboles que pour la figure 1.

\section{Casein dissociation}

Figure 5 shows the non-micellar caseins as the fraction of optical density present in $2 \mathrm{~h}$, $75000 \mathrm{~g}$ supernatants. Non-micellar caseins at $20^{\circ} \mathrm{C}$ appeared to have a peak at $\mathrm{pH}$ 5.4-5.5 in every medium. The fraction of non-micellar caseins at $\mathrm{pH} 5.4-5.5$ determined by HPLC was $7 \%, 30 \%$ and $12 \%$ in water, $\mathrm{NaCl}$ and UF respectively. $\kappa$-Casein was the most important casein in supernatants of NPCS in water and UF ( 38 and $51 \%$ of total non-micellar caseins, respectively) and $\beta$-casein was present at the highest percentage $(43 \%)$ in the supernatant of NPCS in $\mathrm{NaCl}$. A decrease of nonmicellar caseins with decreasing $\mathrm{pH}$ was observed between $\mathrm{pH} 7.4$ and 6.0, particularly for the NPCS in water (fig 5).

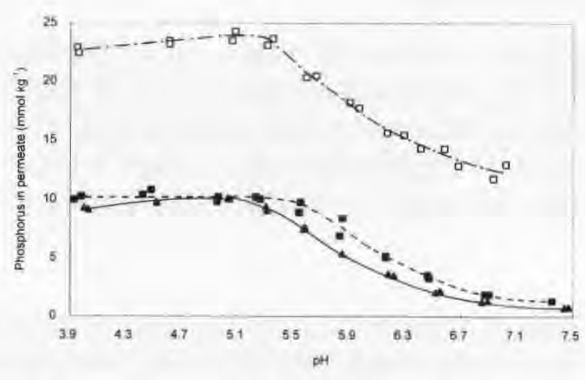

Fig 3. Solubilization of phosphorus from native phosphocaseinate suspensions dissolved in water, $0.1 \mathrm{~mol} \mathrm{~L}^{-1} \mathrm{NaCl}$ and UF with the decrease of $\mathrm{pH}$ at $20^{\circ} \mathrm{C}$. Concentrations of phosphorus in permeates obtained by ultrafiltration on Centriflo CF25 are presented. The $\mathrm{pH}$ values were obtained after the addition of GDL during $15 \mathrm{~h}$ at $20{ }^{\circ} \mathrm{C}$. Two replicates for each medium are presented. Same symbols as in the legend to figure 1.

Solubilisation du phosphore des suspensions de phosphocaséinate natif dans l'eau, $\mathrm{NaCl}$ $0,1 \mathrm{~mol} \mathrm{~L}^{-1}$ et I'UF avec le $\mathrm{pH}$ à $20^{\circ} \mathrm{C}$. Les concentrations en phosphore dans les perméats obtenus sur Centriflo CF25 sont présentées. Les différentes valeurs du $\mathrm{pH}$ était obtenues 15 heures après l'addition de la GDL à $20^{\circ} \mathrm{C}$. Deux répétitions de chaque suspension sont présentées. Mêmes symboles que pour la figure 1. 


\section{Casein precipitation}

Nitrogen contents of $1000 \mathrm{~g}$-supernatant decreased from $95 \%$ to $10 \%$ of total nitrogen around $\mathrm{pH} 5.0$ (fig 6). The $\mathrm{pH}$ value at half precipitation was $5.2,4.7$ and 4.8 for NPCS in water, $0.1 \mathrm{~mol} \mathrm{~L}^{-1} \mathrm{NaCl}$ and UF, respectively. Precipitation appeared less abrupt at higher ionic strength.

\section{Particle size analysis}

Figure 7 shows the decrease of average micelle diameter from $\mathrm{pH} 7.0$ to $5.4-5.5$.

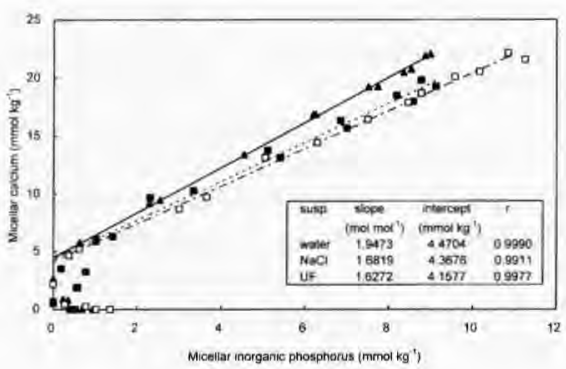

Fig 4. Relation between micellar calcium molar concentration and micellar inorganic phosphorus molar concentration at different $\mathrm{pH}$ values obtained by $\mathrm{GDL}$ addition at $20^{\circ} \mathrm{C}$. Micellar minerals are deduced from differences between diffusible contents (obtained by ultrafiltration at $20{ }^{\circ} \mathrm{C}$ and corrected for non-diffusible elements according to Pierre and Brulé (1981) and total contents. Two replicates are shown for each medium and are combined to give the parameters of linear regression and $\mathrm{r}$, the correlation coefficient. Same symbols as in the legend to figure 1.

Felation entre le calcium micellaire et le phosphore micellaire inorganique à différents $\mathrm{pH}$ obtenus par ajout de $\mathrm{GDL}$ à $20^{\circ} \mathrm{C}$. Les concentrations en minéraux micellaires sont obtenues par différence entre les concentrations diffusibles (obtenues par ultrafiltration à $20{ }^{\circ} \mathrm{C}$ et après correction pour les éléments non diffusibles selon Pierre et Brulé, 1981) et totales. Deux répétitions sont présentées pour chaque suspension et les données des deux répétitions ont été rassemblées pour donner les paramètres de la régression linéaire et $r$, le coefficient de régression. Mêrmes symboles que pour la figure 1 .
The reduction was about $10 \%$ in water and UF and $17 \%$ in $0.1 \mathrm{~mol} \mathrm{~L}^{-1} \mathrm{NaCl}$. $\mathrm{pH}$ values lower than 5.5 caused the micelles to aggregate, and their size can no longer be determined.

\section{Micelle solvation}

Similar shapes for micelle solvation as a function of $\mathrm{pH}$ were observed in the different media (fig 8 ). Minimum solvation was found at $\mathrm{pH} 4.6$, and a maximum peak appeared at $\mathrm{pH} 5.4$. The first minimum for solvation was observed at $\mathrm{pH} 6.6$ in water, at $\mathrm{pH} 6.3$ in $\mathrm{NaCl}$ and at $\mathrm{pH} 6.1$ in UF. Smaller

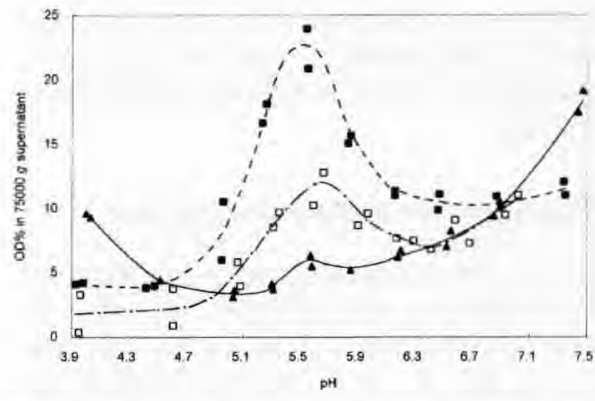

Fig 5. Percents of optical density $(O D \%)$ obtained in $75000 \mathrm{~g}, 2 \mathrm{~h}$ supernatants of native phosphocaseinate suspensions (NPCS), expressed in percent of optical density (OD) in NPCS before centrifugation, as a function of $\mathrm{pH}$ at $20^{\circ} \mathrm{C}$. Values of OD of the two UF used $(5.00$ and 6.04) were deduced from the measured $O D$ of supernatant of NPCS in UF and from the measured OD of NPCS before centrifugation. For details, see Materials and methods. Two replicates are shown for each medium. Same symbols as in the legend to figure 1.

Pourcentage de densité optique $(O D \%)$ des surnageants 2 heures à $75000 \mathrm{~g}$ des suspensions dephosphocaséinate natif (NPCS), exprimée en pourcentage de la densité optique $(O D)$ des NPCS avant centrifugation, en fonction $\mathrm{du} \mathrm{pH}$ à $20{ }^{\circ} \mathrm{C}$. Les valeurs de OD des 2 UF $(5,00$ et 6,04$)$ étaient déduites des valeurs de $O D$ des sumageants des NPCS dissous dans I'UF et des NPCS avant centrifugation. Pourles détails, voir la partie Materials and method. Deux répétitions sont présentées pour chaque suspension. Mêmes symboles que sur la figure 1. 
variations were obtained for phosphocaseinate dissolved in water than in UF or $\mathrm{NaCl}$.

\section{Viscosity measurements}

The relative viscosity decreased from $\mathrm{pH}$ 7.5 to $\mathrm{pH}$ 6.4-6.5 for NPCS in water or $\mathrm{NaCl}$, and from $\mathrm{pH} 7.0$ to $\mathrm{pH} 6.0$ for NPCS in UF (fig 9). The reduction amounted to $10 \%, 7 \%$ and $12 \%$ for water, $\mathrm{NaCl}$ and $\mathrm{UF}$, respectively.

Voluminosity values obtained by viscosimetry and pellet solvation measurement showed the same tendencies: a decrease from $\mathrm{pH} 7.0$ to 6.3 followed by an increase (table III). Values obtained by the two methods exhibit great differences in magnitude. Decreases in voluminosity were stronger for NPCS in UF than in the other medium.

\section{Structure and texture of acid gels}

Gel firmness obtained after acidification were significantly different (at least at $0.04 \%$ ) in the three aqueous phases and decreased as ionic strength increased. Values of $239 \pm 35 \mathrm{~Pa}, 40 \pm 9 \mathrm{~Pa}$ and $52 \pm$ $10 \mathrm{~Pa}$ were calculated, in water, $\mathrm{NaCl}$ and
UF, respectively. It is evident from figure 10 that particles in gel made with water were larger $(305 \pm 141 \mathrm{~nm})$ than with $\mathrm{NaCl}(128$ $\pm 61 \mathrm{~nm})$, and with UF $(150 \pm 84 \mathrm{~nm})$. NPCS dissolved in water appeared to produce a fibrous gel at $\mathrm{pH} 4.4$, with chains made of several particles, entrapping the water in well defined void spaces, while NPCS dissolved in higher ionic strength led to smaller particles aggregated in clusters.

\section{NPCS renneting}

Decreasing the $\mathrm{pH}$ led to reduction of rennet coagulation times as generally observed by others on milk. The $\mathrm{pH}$ effect was stronger between $\mathrm{pH} 7.0$ and 6.5. Between $\mathrm{pH} 5.9$ and 5.5, coagulation times were only slightly dependent on $\mathrm{pH}$, specially for NPCS in UF. Decreasing the ionic strength from $\mathrm{NaCl}$ to water led to high reduction of coagulation times from $23 \mathrm{~min}$ to $8 \mathrm{~min}$ at $\mathrm{pH} 6.7$ and to greater differences at increasing $\mathrm{pH}$ values. From $\mathrm{pH} 7.0$ to 6.7 , rennet coagulation times decreased from $\mathrm{UF}$ to $\mathrm{NaCl}$ medium, while for $\mathrm{pH}$ values lower than 6.7, higher coagulation times were observed for $\mathrm{NaCl}$ suspensions.

Table III. Effect of $\mathrm{pH}$ on casein voluminosity at $20^{\circ} \mathrm{C}$. $\mathrm{V}_{\text {pellet }}$ and $\mathrm{V}_{\text {visc }}$ are the casein voluminosity obtained from pellet hydration measurements and viscosity measurements on native phosphocaseinate suspensions.

Effet du pH sur la voluminosité des caséines à $20^{\circ} \mathrm{C}$. $V_{\text {pellet }}$ and $V_{\text {visc }}$ sont les voluminosités obtenues à partir des mesures de l'hydratation des culots et des mesures de viscosité sur les suspensions de phosphocaséinate natif.

\begin{tabular}{|c|c|c|c|c|c|}
\hline \multirow[t]{2}{*}{ Aqueous phase } & & \multicolumn{4}{|c|}{ 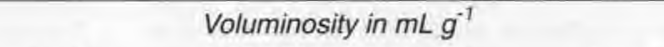 } \\
\hline & & $p H 7.0$ & pH 6.3 & pH 5.6 & $\Delta \max { }^{*}$ \\
\hline \multirow[t]{2}{*}{ Water } & $V_{\text {pellet }}$ & 2.67 & 2.57 & 2.73 & 0.10 \\
\hline & $V_{\text {visc }}$ & 3.39 & 2.90 & 3.22 & 0.49 \\
\hline \multirow[t]{2}{*}{$0.1 \mathrm{~mol} \mathrm{~L}^{-1} \mathrm{NaC}$} & $V_{\text {pellet }}$ & 3.19 & 3.03 & 3.18 & 0.27 \\
\hline & $\mathrm{V}_{\text {visc }}$ & 4.90 & 4.09 & 5.06 & 0.90 \\
\hline \multirow[t]{2}{*}{ UF } & $V_{\text {pellet }}$ & 2.82 & 2.42 & 2.51 & 0.43 \\
\hline & $V_{\text {visc }}$ & 5.03 & 3.59 & 3.74 & 1.76 \\
\hline
\end{tabular}

Maximal reduction of voluminosity.

* Réduction maximale de la voluminosité. 


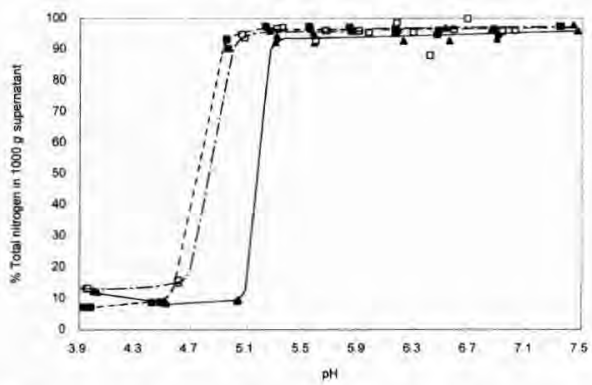

Fig 6. Total nitrogen content (TN) of $1000 \mathrm{~g}, 1 \mathrm{~h}$ supernatants of the native phosphocaseinate suspensions (expressed in percentages of total nitrogen of non-centrifuged samples), as a function of $\mathrm{pH}$ at $20^{\circ} \mathrm{C}$. Total nitrogen is obtained by Kjeldahl method with a 6.38 coefficient. Two repetitions are shown for each medium. Same symbols as in the legend to figure 1.

Azote total (TN) des sumageants 1 heure, $1000 \mathrm{~g}$ des suspensions de phosphocaséinate natif (exprimé en pourcents de l'azote total des échantillons non centrifugés) en fonction $\mathrm{du} \mathrm{pH}$ à $20{ }^{\circ} \mathrm{C}$. L'azote total était obtenu par la méthode de Kjeldahl avec un coefficient de 6,38. Deux répétitions sont présentées pour chaque suspension. Mêmes symboles que sur la figure

\section{DISCUSSION}

\section{The effect of the aqueous phase on the initial NPCS}

Diffusible salts being responsible for about $50 \%$ of the buffering of milk (Lucey et al, 1993), it was not surprising that the buffering of micelle suspension was greater in UF (fig 1).

According to Brulé et al (1974), Van Hooydonk et al (1986b) and Le Graet and Brule (1993), the addition of $0.1 \mathrm{~mol} \mathrm{~L}^{-1}$ $\mathrm{NaCl}$ in milk at $\mathrm{pH} 6.7$ leads to about a $0.75-1.00 \mathrm{mmol} \mathrm{kg}^{-1}$ diffusible calcium increase (11\% increase) and no diffusible phosphorus increase. In this study, the solubilization of phosphocaseinate powder in $\mathrm{NaCl}$, compared to solubilization in water led to a solubilization of $2.662 \mathrm{mmol} \mathrm{kg}^{-1}$ of calcium and of $0.758 \mathrm{mmol} \mathrm{kg}^{-1}$ of phosphorus from the colloidal calcium phos-

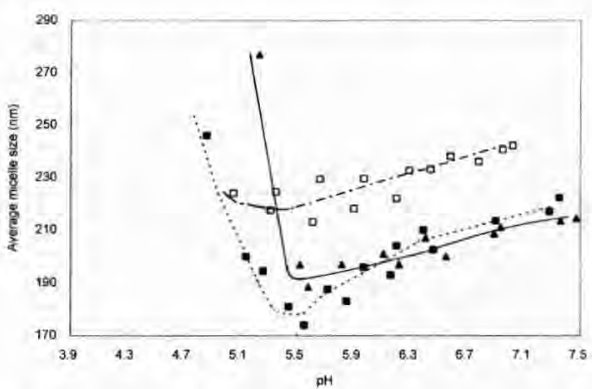

Fig 7. Average micelle size obtained by a light scattering method on Coulter N4MD, as a function of $\mathrm{pH}$, at $20^{\circ} \mathrm{C}$. Preparation of native phosphocaseinate in each aqueous phase was carried out in duplicate. From each suspension, two samples at each $\mathrm{pH}$ value were prepared. Each point of the curve is the mean of these two samples. Same symbols as in the legend to figure 1.

Taille moyenne des micelles obtenue par diffusion de la lumière à l'aide du Coulter N4MD en fonction $\mathrm{du} \mathrm{pH}$, à $20^{\circ} \mathrm{C}$. La préparation des suspensions dans chaque phase aqueuse a été réalisée en double. À partir d'une suspension, deux échantillons à chaque $\mathrm{pH}$ ont été préparés. Chaque point de la courbe est une moyenne de ces deux échantillons. Mêmes symboles que sur la figure 1.

phate (CCP) (mean values from table II). According to a hypothetical tricalciumphosphate composition $(\mathrm{Ca} / \mathrm{P}=1.5 \mathrm{~mol}$ $\mathrm{mol}^{-1}$ ), the increase of ionic strength due to $\mathrm{NaCl}$ caused solubilization of $0.758 \mathrm{mmol}$ $\mathrm{kg}^{-1}$ phosphorus and this would correspond to solubilization of $1.137 \mathrm{mmol} \mathrm{kg}^{-1}$ of calcium bound to phosphorus. It follows that $43 \%$ of $\mathrm{NaCl}$-solubilized-calcium was bound to phosphorus and $57 \%$ likely bound to the phosphoserine residues. This solubilization of the CCP occurred because, first, the diffusible phase of the NPCS dissolved in $\mathrm{NaCl}$ was not saturated with calcium phosphate, as in milk and, second, because an increase in ionic strength is known to produce a decrease of the free ion activity coefficient. This increases the stochiometric solubility product of salts and consequently, the concentration of ionic 


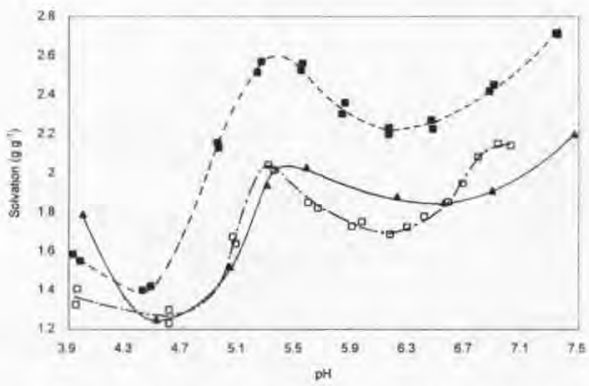

Fig 8. Pellet solvation in $\mathrm{g}$ of water per $\mathrm{g}$ of dry pellet as a function of $\mathrm{pH}$, at $20^{\circ} \mathrm{C}$. Drained pellet obtained after $75000 \mathrm{~g}, 2 \mathrm{~h}$ centrifugation of native phosphocaseinate suspensions were dried at $103^{\circ} \mathrm{C}$ for $7 \mathrm{~h}$. Two repetitions are shown for each medium. Same symbols as in the legend to figure 1.

Hydratation des culots en g d'eau parg de culot sec en fonction $d u \mathrm{pH}$ à $20^{\circ} \mathrm{C}$. Les culots obtenus par centrifugation des suspensions de phosphocaséinate natif à $75000 \mathrm{~g}, 2$ heures, étaient égouttés et séchés à $103^{\circ} \mathrm{C}$ pendant 7 heures. Deux répétitions sont montrées pour chaque suspension. Mêmes symboles que sur la figure 1 .

species such as calcium phosphate. Anyway, it is well known that sodium added tends to partly displace calcium from the $\mathrm{CCP}$ to the aqueous phase. According to Grufferty and Fox (1985) and Le Graet and Brulé (1993), calcium directly bound to phosphoseryl residues is affected by added $\mathrm{NaCl}$.

\section{The effect of the aqueous phase on the acidification process}

The diffusible mineral values with $\mathrm{pH}$ decrease obtained for NPCS in UF are within the range of values published elsewhere (Dalgleish and Law, 1989; Le Graet and Brulé, 1993). The two ultrafiltrates used were not exactly the same (table II), which would explain the discrepancy seen in figures 2 and 3 for NPCS dissolved in UF.

The differences in mineral solubilization with acidification between water, $\mathrm{NaCl}$ and UF are difficult to explain, because the dis-

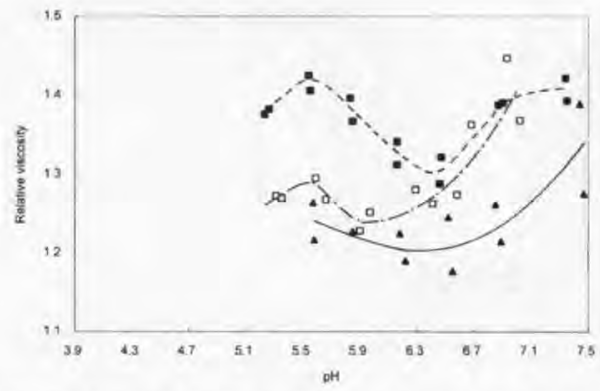

Fig 9. Relative viscosity of native phosphocaseinate suspensions obtained from viscosity measured in coaxial cylinder at $94.5 \mathrm{~s}^{-1}$ strain rate and $20^{\circ} \mathrm{C}$. Relative viscosity (suspension viscosity/solvent phase viscosity) was obtained using $1.00,0.95$ and 1.09 measured values for viscosity of water, $0.1 \mathrm{~mol} \mathrm{~L}^{-1} \mathrm{NaCl}$ and UF, respectively. Two repetitions are shown for each medium. Same symbols as in the legend to figure 1.

Viscosité relative des suspensions de phosphocaséinate natif obtenue par viscosimétrie sur cylindres coaxiaux à une vitesse de déformation de $94,5 \mathrm{~s}^{-1}$ à $20{ }^{\circ} \mathrm{C}$. Les valeurs mesurées de la viscosité de l'eau $(1,00), \mathrm{NaCl} 0,1 \mathrm{~mol} \mathrm{~L}^{-1}$ $(0,95)$ et I'UF $(1,09)$ servaient au calcul de la viscosité relative (viscosité de la suspension/viscosité de la phase solvante). Deux répétitions sont montrées pour chaque suspension. Mêmes symboles que sur la figure 1 .

solution of the phosphocaseinate powder in the aqueous phase (notably in water and $\mathrm{NaCl}$ ) can lead to a mineral solubilization (table II). Total mineral solubilization obtained with the $\mathrm{pH}$ reduction was observed at higher $\mathrm{pH}$ values for NPCS dissolved in $\mathrm{NaCl}$ (figs 2,3). On the one hand, the increased ionic strength led to a higher salt solubility (Walstra and Jenness, 1984). On the other hand, the increase in ionic strength caused a lower apparent $\mathrm{pK}$ value for ionic groups of caseins and consequently a retardation of the mineral solubilization (Baumy et al, 1989). This explained the lower $\mathrm{pH}$ values obtained for nitrogen precipitation when micelles were suspended in a higher ionic strength medium (fig 6). Slopes and intercepts for linear relations between micellar calcium and mi- 

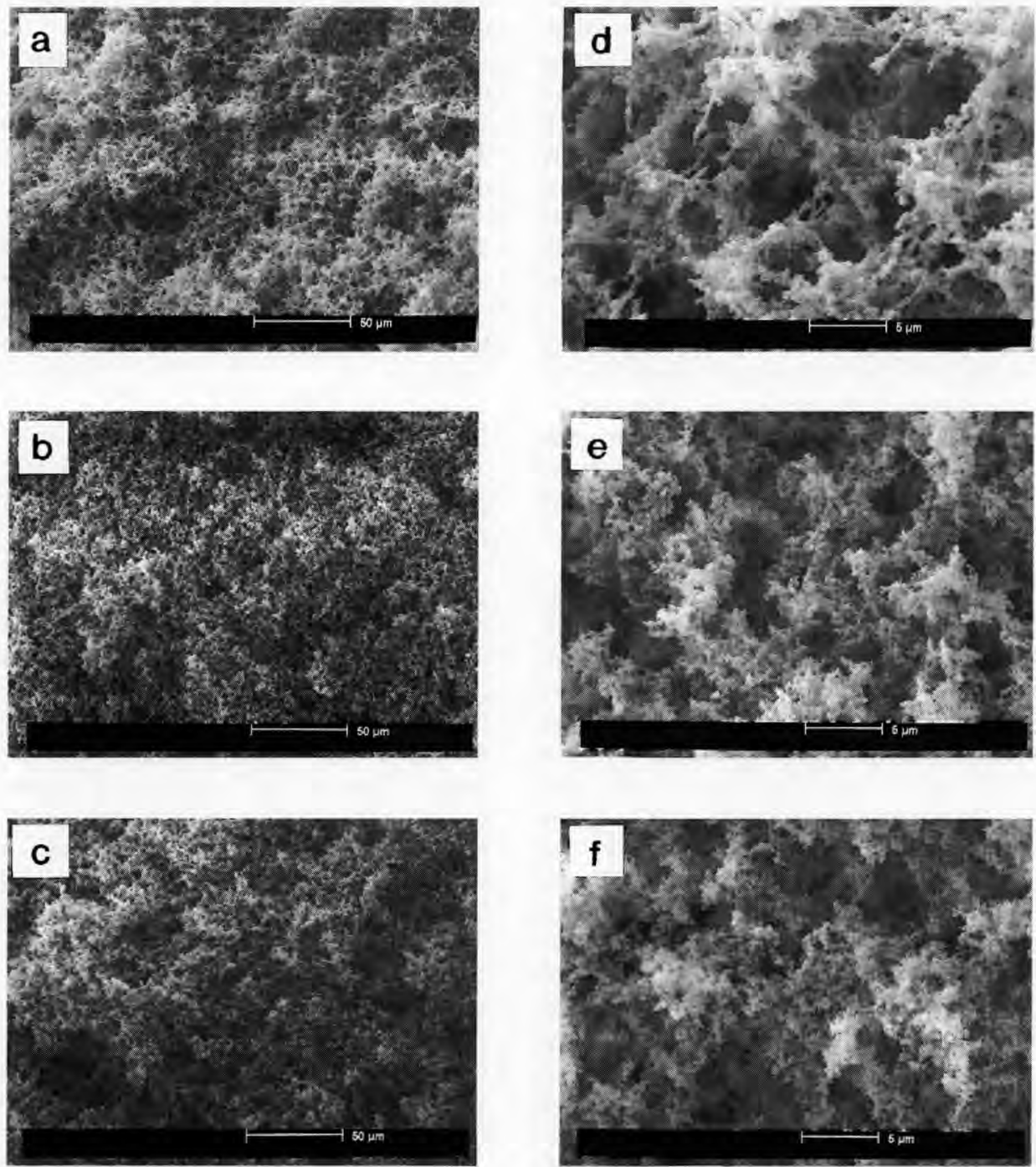

Fig 10. SEM micrographs of gel at pH 4.4 obtained with GDL for native phosphocaseinate suspensions (NPCS) in water (a, d), $0.1 \mathrm{~mol} \mathrm{~L}^{-1} \mathrm{NaCl}(\mathbf{b}, \mathbf{e})$ and UF (c, f), at two different magnifications. In water, casein particles were larger, and gel appeared as a fibrous network of chained particles, with well-defined void spaces. The gel of NPCS in NaCl or UF was composed of clusters of smaller particles with large, and diffuse void spaces.

Images de microscopie à balayage des gels à $\mathrm{pH} 4,4$ obtenus avec la $\mathrm{GDL}$ à partir des suspensions de phosphocaséinate natif (NPCS) dans l'eau (a et d), $\mathrm{NaCl} 0,1 \mathrm{~mol} \mathrm{~L}^{-1}$ (b et e) et I'UF (c et f), à deux grandissements différents. Dans l'eau, les particules caséiniques étaient plus grandes, et le gel apparaissait comme un réseau fibreux de particules en chaînettes, avec des pores bien définis. Le gel obtenu pour le NPCS dans NaCl ou l'UF était composé de paquets agglomérés de particules plus petites, avec des pores de taille moins bien définie. 
cellar inorganic phosphorus for NPCS in UF were in total agreement with the range of values cited in Dalgleish and Law (1989) (1.61-1.98 $\mathrm{mol} \mathrm{Ca} /$ mole P). The slopes were higher for NPCS dissolved in water, suggesting that micellar calcium directly bound to casein was solubilized together with the colloidal calcium phosphate. This suggests that the calcium dissociation with $\mathrm{pH}$ can be differently affected by the ionic strength.

In the changes occurring during lowering of the $\mathrm{pH}$ some successive stages can be conveniently distinguished. The various changes occurring are dependent on each other. Dissociation of casein from the $\mathrm{mi}$ celles and changes in solvation are involved.

\section{Phase I}

The $\mathrm{pH}$ ranges of this step were from $\mathrm{pH}$ $7.0-7.5$ to 6.6 , to $\mathrm{pH} 6.3$ and to 6.1 for NPCS dissolved in water, $\mathrm{NaCl}$ and UF, respectively. Micelle size, micelle solvation, and viscosity decreased during this step as described by Roefs et al (1985) on milk at $8{ }^{\circ} \mathrm{C}$, by Van Hooydonk et al (1986a) and by Banon and Hardy (1991, 1992). This is in accordance with a voluminosity decrease due to the ionisation regression as the $\mathrm{pH}$ decreased. This led, first, to less negatively charged proteins and hence to the reduction of repulsive forces between adjacent chains. This results in the onset of the progressive collapse of the outer-hairylayer described by Banon and Hardy (1992) between pH 6.6 and 5.8 in milk at $20{ }^{\circ} \mathrm{C}$. Second, and well established, the protonation of mineral phosphate led to the dissociation of calcium and phosphorus.

During this phase, less mineral matter dissociated from micelles in water, and more was dissolved from micelles in $\mathrm{NaCl}$, compared with micelles in UF. It can be concluded that it was not directly the mineral solubilization that governed the physicochemical changes, and that the increase in ionic strength led to increased mineral solubilization in these ranges of $\mathrm{pH}$, probably because solubility of calcium phosphate is increased by higher ionic strength.

It is noteworthy that, during this step, a decrease of non-micellar caseins was observed, particularly for the NPCS in water (fig 5). A similar decrease was observed in the study of Dalgleish and Law (1988), but only at $30{ }^{\circ} \mathrm{C}$. It can be suggested that some non-micellar caseins present in NPCS dissolved in water may return to the micelles, due to the reduction of repulsive forces between charged amino acids residues.

\section{Phase II}

This step ended at $\mathrm{pH} 5.5-5.6$, at which the casein dissociation was maximal, as in Dalgleish and Law (1988) on milk at $20^{\circ} \mathrm{C}$. As the mineral content of micelles further decreased, viscosity, casein solvation and casein dissociation from micelles seemed to increase. This can be explained by the reduction of electrostatic interactions between caseins, and the subsequent increase of water-casein interactions. Micelles placed in $\mathrm{NaCl}$ exhibited a greater voluminosity (fig 8), and more casein dissociation (fig 5). Replacement of calcium by sodium or addition of $\mathrm{NaCl}$ in milk is known to increase the milk viscosity and the water-holding properties of casein micelles. This is explained, on the one hand, by changes in the structure of micelles probably due to the displacement of calcium from the CCP by sodium and, on the other hand, by the increase of the ionisation of caseins due to the decrease of activity coefficients. The latter led to the increase of the micelle voluminosity and also of the functional properties of casein material (Burgess, 1982; Snoeren et al, 1984; Creamer, 1985).

Casein solubilization values at $\mathrm{pH}$ 5.45.5 for NPCS in UF (12\%) were smaller than the values obtained by Daigleish and Law (1988) for milk at $20^{\circ} \mathrm{C}(30 \%)$. Release of soluble casein during microfiltration of the phosphocaseinate (TN-NCN in 
microfiltrates was less than $5 \%$ ) prior to its drying process might account for this discrepancy. $\kappa$ - and $\beta$-caseins were mainly released from the micelles, because $\kappa$-casein is supposed to be mainly located at the micellar surface and $\beta$-casein is able to diffuse out of the micelle. Supernatants of $\mathrm{NPCS}$ in $\mathrm{NaCl}$ were enriched in $\beta$-casein, though ionic strength increase is known to have a negative effect on $\beta$-casein extraction (Famelart et al, 1989).

According to Van Hooydonk et al (1986a), the swelling of micelles between $\mathrm{pH} 6.0$ and 5.6 is only explained by the solubilization of the CCP. An increase in ionisation or in hydrophilic characteristics of molecules leads to an increase in amphiphilic properties, ie an increase of the tendency of hydrophobic part to cluster. Experiments on the effect of heating on milk proteins (Haque and Kinsella, 1988) show that hydrophobic side chains residues were withdrawn within proteins, while ionisable residues were more exposed. When the charge of proteins is reduced by $\mathrm{pH}$ changes of the eluant in high-performance hydrophobic interaction chromatography, hydrophobic interactions increase, and vice versa, which means that hydrophobic residues are less withdrawn in the core of the protein when less ionised (Fausnaugh and Regnier, 1986; Hjerten et al, 1986). Hydrophilicity of proteins would affect the exposure of hydrophobic residues, ie, the contribution of hydrophobicity to the formation and stability of protein complexes. It might be possible that during the decrease of ionic interactions between casein and between casein and water, a substantial reduction of hydrophobic interactions took place, leading to the swelling of micelles or even of submicellar units.

Micelle voluminosity increased during this step, while the micelle diameter showed only a further decrease. The weakening of internal bonds of the micelle led to its swelling. This disaggregation led to the decrease in diameter because free submi- celles are leaving the micelle, despite an increase in voluminosity.

\section{Phase III}

Between $\mathrm{pH} 5.5-5.6$ and $\mathrm{pH} 5.3-5.4$, casein dissociation decreased, while the average micelle size and solvation increased. According to Snoeren et al (1984), the peak in solvation may be partly due to the dissociation of $\beta$-casein from the micelles. This unexpected observation of solvation increase and casein dissociation decrease was already mentioned by Van Hooydonk et al (1986a), while according to Roefs et al (1985), this discrepancy is absent in the cold. The solvation changes being mainly due to the changes of the micellar structure, it is then possible to observe a decrease in 'soluble' casein, despite a solvation increase. As the $\mathrm{pH}$ decreased, new interactions, probably hydrophobic and electrostatic, occurred between these caseins in free submicelles, which explained the reduction in 'soluble' caseins. The caseins are held together by these new interactions and we assumed that this new structure is able to retain more water, because less deformable during the centrifugation stress. Interactions being reduced at $4{ }^{\circ} \mathrm{C}$, the less rigid structure did not show this behaviour: casein solvation and dissociation decreased simultaneously in the cold.

\section{Phase IV}

The decrease of solvation and of soluble total nitrogen from $\mathrm{pH} \mathrm{5.3-5.4}$ to $4.4-4.6$ were due to casein precipitation at the isoelectric $\mathrm{pH}$, caused by the general charge neutralisation. The effect of ionic strength on the isoelectric $\mathrm{pH}$ values of the four caseins is substantially different. This is expected from the comparison of isoionic $\mathrm{pH}$ values calculated in Swaisgood (1992) and isoelectric $\mathrm{pH}$ values. This explained that the decrease of soluble nitrogen with $\mathrm{pH}$ was less abrupt for high ionic strength suspensions (fig 6). 


\section{Phase V}

Below the $\mathrm{pH}$ of minimal solvation, ie, the isoelectric $\mathrm{pH}(\mathrm{pH} 4.4-4.6)$, casein began to be positively charged. Water-holding properties of proteins increased, as the 'soluble' casein contents. Negative ionisation of phosphate groups at these $\mathrm{pH}$ values (pK 3; Walstra and Jenness, 1984) would explain adsorption of inorganic phosphate on acid casein (fig 3 ) as described by Le Graet and Brulé (1993).

\section{The effect of the aqueous phase on acid gels}

Reliable correlations between microstructure and firmness in acid gels were already mentioned, depending on the temperature, the acidulant used, and the $\mathrm{pH}$ values (Harwalkar and Kalab, 1981, 1986; Kalab et al, 1983). Gels in the form of coarse clusters, with large pores result in low firmness, while a more continuous protein network with chained particles exhibit greater firmness. Increasing ionic strength of $\mathrm{Na}$-caseinate with increasing amounts of $\mathrm{NaCl}$ is known to produce acid gels with lower modules (Roefs and Van Vliet, 1990). In this study, the particles in acid gels of higher ionic strength were smaller and the gels appeared as coarse clusters of particles. Gels of NPCS in water at pH 4.4 are composed of particles with a higher net positive charge than in higher ionic strength. This is clearly demonstrated in figure 6 , were the $\mathrm{pH}$ at half precipitation was 5.2 for micelles in water and about 4.7 for high ionic strength. The higher positive charge of particles in water may first prevent interparticle interactions, resulting in a finer and chained gel, and second, resulted in a swelling of casein particles.

\section{The effect of the aqueous phase on rennet coagulation time}

The reduction of ionic strength of the NPCS markedly decreased the rennet coagula- tion time. Reduced rennet clotting time for native phosphocaseinate compared with milk was already mentioned by Pierre et al (1992). We observed (Famelart, unpublished work) that the reconstitution of the phosphocaseinate used in this study in 0 to $0.12 \mathrm{~mol} \mathrm{~L}^{-1} \mathrm{NaCl}$ solutions resulted in the decrease of both the enzymatic and the aggregation rates. An increase in rennet clotting time with ionic strength increase was previously observed by Visser et al (1980) on model substrates, and by Grufferty and Fox (1985) and Van Hooydonk et al (1986b) on milk, provided that the $\mathrm{pH}$ after the salt addition has been corrected. Ionic strength increase is supposed to screen the negative charge on chymosin and the positive clusters in $\kappa$-casein near the Phe105-Met106 peptide linkage, and to lower the enzyme-substrate attraction (Visser et al, 1980).

Curves of relative viscosity versus $\mathrm{pH}$ -reflecting micelle voluminosity- and of rennet coagulation times from $\mathrm{pH} 7.0$ to 6.3 were very close, with substantially lower voluminosity in water. In our opinion, and with the suggestion that rennet-induced aggregation is diffusion-controlled (Van Hooydonk et al, 1984; Famelart, 1994), steric repulsions due to increased voluminosity in $\mathrm{NaCl}$ and UF were mainly responsible for long coagulation times and for the changes in rennet coagulation time from $\mathrm{pH} 7$ to 6.3. At lower $\mathrm{pH}$ values, the reduction of negative charge would have played the major part.

\section{CONCLUSION}

Native phosphocaseinate used in this study might be regarded as a relevant model of milk micelles. It raised the possibility of studying the effect of the aqueous phase on the mineral exchanges between diffusible and colloidal phases and the behaviour of the micelles toward acidification or rennet processes in the absence of whey proteins. It is relevant to mention that it con- 
sists of an attractive substrate for technological milk processing such as yoghurt and cheese manufacture. NPCS dissolved in UF behave like native milk. Moreover, when dissolved in water, the micelle suspension is able to form a strong gel at acidic $\mathrm{pH}$ and to coagulate with rennet at shorter times than milk, as already shown by Pierre et al (1992).

\section{ACKNOWLEDGMENTS}

The authors are indebted to $\mathrm{J}$ Berrier for help in SEM preparation and observation, and to $F$ Michel for help in micelle size measurements.

\section{REFERENCES}

Banon S, Hardy J (1991) Study of acid milk coagulation by an optical method using light reflection. J Dairy Res 58, 75-84

Banon S, Hardy J (1992) A colloidal approach of milk acidification by glucono-delta-lactone. J Dairy Sci 75, 935-941

Baumy JJ, Guenot P, Sinbandhit S, Brulé G (1989) Study of calcium binding to phosphoserine residues of $\beta$-casein and its phosphopeptide $(1-25)$ by ${ }^{31} \mathrm{P}$ NMR. J Dairy Res 56, 403-409

Brulé G, Maubois JL, Fauquant J (1974) Étude de la teneur en éléments minéraux des produits obtenus lors de l'ultrafiltration du lait sur membrane. Lait 54. 600-615

Burgess KJ (1982) lon exchange processing of skimmilk for food use. J Dairy Res 49, 749

Creamer LK (1985) Water absorption by renneted casein micelles. Milchwissenschaft 40, 589-591

Dalgleish DG (1984) Measurement of electrophoretic mobilities and zeta-potentials of particles from milk using laser Doppler electrophoresis. J Dairy Res 51 , 425-438

Dalgleish DG, Law AJR (1988) pH-Induced dissociation of bovine casein micelles. I. Analysis of liberated caseins. J Dairy Res 55, 529-538

Dalgleish DG, Law AJR (1989) pH-Induced dissociation of bovine casein micelles. II. Mineral solubilization and its relation to casein release. $J$ Dairy Res 56 , 727-735

Darling DF, Dickson J (1979) Electrophoretic mobility of casein micelles. J Dairy Res 46, 441-451

Driehuis F, Teernstra EJM (1992) Method for turbidimetric estimation of lactic acid bacteria in fat-containing milk. Neth Milk Dairy J 46, 209-215

Famelart MH (1994) Rennet coagulation of milk in the presence of sucrose. J Dairy Res 61, 473-483

Famelart MH, Hardy C, Brulé G (1989) Étude des facteurs d'extraction de la caséine $\beta$. Lait $69,47-57$

Fauquant J, Maubois JL, Pierre A (1988) Microfiltration du lait sur membrane minérale. Tech Lait 1028, 21-23
Fausnaugh JL, Regnier FE (1986) Solute and mobile phase contributions to retention in hydrophobic interaction chromatography of proteins. J Chromatogr 359, 131-146

Grufferty MB, Fox PF (1985) Effect of added $\mathrm{NaCl}$ on some physicochemical properties of milk. Ir J Food Sci Technol 9, 1-9

Haque Z, Kinsella JE (1988) Interaction between heated $\kappa$-casein and $\beta$-lactoglobulin: predominance of hydrophobic interactions in the initial stages of complex formation. J Dairy Res $55,67-80$

Harwalkar VR, Kalab M (1981) Effect of acidulants and temperature on microstructure, firmness and susceptibility to syneresis of skim milk gels. Scan Electron Microsc 3, 503-513

Harwalkar VR, Kalab M (1986) Relationship between microstructure and susceptibility to syneresis in yoghurt made from reconstituted nonfat dry milk. Food Microstruct 5, 287-294

Heertje I, Visser J, Smits P (1985) Structure formation in acid milk gels. Food Microstruct 4, 267-277

Hjerten S, Yao K, Eriksson KO, Johansson B (1986) Gradient and isocratic high-performance hydrophobic interaction chromatography of proteins on agarose columns. J Chromatogr 359, 99-109

Holt C (1985) The milk salts: their secretion, concentrations and physical chemistry. In Developments in Dairy Chemistry. Vol 3. Lactose and minor constituents (PF Fox, ed), Elsevier, London

International Dairy Federation (1987) Determination of total phosphorus content (Photometric method). Int Standard FIL-IDF $33 \mathrm{C}$

Jaubert A, Martin P (1992) Reverse phase HPLC analysis of goat caseins. Identification of $\alpha_{S 1}$ and $\alpha_{S 2}$ genetic variants. Lait 72, 235-247

Kalab M, Allan-Wojtas P, Phipps-Todd BE (1983) Development of microstructure in set-style yoghurt - A review. Food Microstruct 2, 51-66

Korolczuk J, Mahaut M (1988) Studies of cheese texture by a computerized, constant speed, cone penetrometer. Lait 68, 349-362

Le Graet P, Brulé G (1993) Les équilibres minéraux du lait: influence du $\mathrm{pH}$ et de la force ionique. Lait 73 , $51-60$

Lucey JA, Hauth B, Gorry C, Fox PF (1993) The acidbase buffering properties of milk. Milchwissenschaft $48,268-271$

Pierre A, Brulé G (1981) Mineral and protein equilibria between the colloidal and soluble phases of milk at low temperature. J Dairy Res 48, 417-428

Pierre A, Michel F, Le Graet Y (1995) Variation in size of goat milk casein micelles related to casein genotype. Lait 75, 489-502

Pierre A, Fauquant J, Le Graet Y, Piot M, Maubois JL (1992) Préparation de phosphocaséinate natif par microfiltration sur membrane. Lait 72, 461-474

Roefs SPFM, Van Vliet T, (1990) Structure of acid casein gels 2. Dynamic measurements and type of interaction forces. Colloids Surfaces 50, 161-175 
Roefs SPFM, Walstra P, Dalgleish DG, Horne DS (1985) Preliminary note on the change in casein micelles caused by acidification. Neth Milk Dairy J 39, 119-122

Salles C, Dalmas S, Septier C, Issanchou S, Noel Y, Etievant P, Le Quéré JL, (1995) Production of a cheese model for sensory evaluation of flavour compounds. Lait 75, 535-549

Schmidt DG, Poll JK (1986) Electrokinetic measurements on unheated and heated casein micelle systems. Neth Milk Dairy J 40, 269-280

Schuck P, Piot M, Méjean S, Le Graet Y, Fauquant J, Brulé G, Maubois JL (1994) Déshydratation par atomisation de phosphocaséinate natif obtenu par microfiltration sur membrane. Lait 74, 375-388

Snoeren THM, Klok HJ, Van Hooydonk ACM, Damman AJ (1984) The voluminosity of casein micelles. Milchwissenschaft $39,461-463$

Swaisgood HE (1992) Chemistry of the caseins. In: Advanced Dairy Chemistry. Vol 1. Proteins (PF Fox, ed), Elsevier, London

Tarodo de la Fuente B, Alais C (1975) Solvation of casein in bovine milk. J Dairy Sci 58, 293-300
Van Hooydonk ACM, Olieman C, Hagedoorn HG (1984) Kinetics of the chymosin-catalysed proteolysis of $\kappa$ casein in milk. Neth Milk Dairy J 38, 207-222

Van Hooydonk ACM, Hagedoorn HG, Boerrigter IJ (1986a) $\mathrm{pH}$-induced physico-chemical changes of casein micelles in milk and their effect on renneting. 1. Effect of acidification on physico-chemical properties. Neth Milk Dairy J 40, 281-296

Van Hooydonk ACM, Hagedoorn HG, Boerrigter IJ (1986b) The effect of various cations on the renneting of milk. Neth Milk Dairy J 40, 369-390

Visser J, Minihan A, Smits P, Tjan SB, Heertje I (1986) Effects of $\mathrm{pH}$ and temperature on the milk salts system. Neth Milk Dairy J 40, 351-368

Visser S, Van Rooijen PJ, Slangen C (1980) Peptide substrates for chymosin (rennin). Isolation and substrate behaviour of two tryptic fragments of bovine $\kappa$-casein. Eur J Biochem 108, 415-421

Walstra P, Jenness R (1984) Dairy chemistry and physics. John Wiley and Sons, New York 